\title{
Musical Expression of Sholawat Art in Multicultural Societies: A Study of Composition Forms
}

\author{
Luthfi bin Yahya ${ }^{1}$, Moh. Muttaqin ${ }^{2 \bowtie}$, Ibnu Amar Muchsin ${ }^{2}$ \\ ${ }^{1}$ President Advisory Board, Indonesia \\ ${ }^{2}$ Universitas Negeri Semarang, Indonesia
}

Submitted: September 16, 2020. Revised: November 29, 2020. Accepted: December 4, 2020

\begin{abstract}
This study is based on society's reality about the diversity of musical expressions of the sholawat art which is still ongoing. Therefore, this study aims to identify, analyze, and describe the musical expressions of sholawat art that exist in society in the context of a multicultural society. This study is a qualitative descriptive study with a musicology approach as the main approach. This study used several techniques for data collection, namely interview techniques, document and documentation study techniques, and observation techniques. Furthermore, the data were analyzed using content analysis with the main musicological approach which refers to the concept of composition, harmony, song form, and presentation form. The results show that in a multicultural society, such as Indonesia, there are various kinds of musical expressions of sholawat art. If we look at musicology, the diversity of musical expressions includes several kinds of expressions, which include the variety in characterization, the variety in the scale tradition used, the mixture in the use of song lyrics, and the variety in the technique of using language in composing the lyrics.
\end{abstract}

Keywords: musical expression; sholawat art; multiculturalism; composition

How to Cite: Yahya, L., Muttaqin, M., \& Muchsin, I. A. (2020). Musical Expression of Sholawat Art in Multicultural Societies: A Study of Composition Forms. Harmonia: Journal of Arts Research And Education, 20(2), $242-251$

\section{INTRODUCTION}

Indonesia's territory consists of about 16,000 large and small islands and is inhabited by more than 400 large and small ethnic groups who embrace various major religions (Melaletoa \& Dloyanah, 1995). The major religions are Islam, Protestantism, Catholicism, Buddhism, Confucianism, Hinduism, and belief in the One and Only God with various cultural forms and forms (Soedarsono, 2001). This amount also means that Indonesia has various forms and varieties of art in each of these ethnic groups, including various per- forming arts. One of them is the variety of performing arts is the performing arts of sholawat music.

The art of sholawat is one of the developing arts in Indonesia. In the context of the culture of the Muslim community, praying is an order of religious teachings as stated in the Qur'an surah al-Ahzab: 56, which means: Verily Allah and His angels pray for the Prophet, O Believers, pray for the Prophet Respect to him (Surah Al Ahzab: 56). Along with the conditions of the diversity of cultures, ethnicities, languages, arts that exist and develop in Indonesia, this situation will influence the

\footnotetext{
Corresponding author:

E-mail: muttaqinm@mail.unnes.ac.id
} 
community in expressing or expressing the art of sholawat music so that there may be various kinds of expressions of sholawat art that occur and develop in society. This art can be expressed in multiple forms of presentation and in a very diverse context, both related to its function and expression itself, as well as in certain moments.

Many writers have done a number of previous writings on the art of sholawat and its expression, for example by; (1) Wahyuni and Pujianti (2019), who review sholawat from the semantic side of the Connotative Meaning of the Qasidah Salawat of the Prophet's Syair in the Manuscript of the Council of Dhikr and Salawat Pondok Rumi for the Al-Asyiqin Jambi Council (Semantic Study) and reviewing sholawat from the perspective of developing sholawat offerings about the media. Tutik, et al. (2020) reviewed the relationship between puji-pujian (praise song, adzan (after the call to prayer) and the development of intelligence. Fahruroji \& Azhar (2017) also conducted a review of sholawat from the Qur'an and hadith. This study provides an overview of this prayer's implications in the interpretation and establishment of laws and semantically analyzing the sholawat to the Prophet Muhammad S.A.W.

From some writings on sholawat, it can be argued that there has not been one single article that specifically examines musical expression in prayer offerings in a multicultural society. Even if there is, the study carried out is deemed incomplete and still simple.

According to Poole (1996), as cited by Suharto (1996), multiculturalism is a political principle which states that the government should act to protect and maintain social diversity that occurs in plural societies. The maintenance is, at least, by preventing discrimination on the basis of cultural identity and non-discrimination in government practices (negative multiculturalism), and perhaps also by acting positively to ensure the sustainable survival of minority cultures (positive multiculturalism) (Poole, 1997). In multiculturism education, it is an idea, movement, educa- tional reform, and educational process that aims to change educational institutions' structure so that students who are members of various racial, ethnic and cultural groups will have the same opportunity to achieve academic achievement in school (Suharto, 1996).

A multicultural society consists of different cultural communities with all the benefits and slight differences in the world's concept, systems of meaning, values, organizational forms, history, customs, and existing habits. A multicultural society is a term used to describe a person's view or opinion regarding various life on earth, or a policy that emphasizes the acceptance of cultural diversity, as well as a variety of cultures, multiple values of society, systems, cultures, customs, and also their politics (Parekh, 2001). The different conditions of society in terms of values, social, ethnicity, religion, and culture are very likely to affect expression activities, including music, which he does.

Expression in music is the expression of thoughts and feelings that include all the nuances of tempo, dynamics, and tone colors of the main elements of music in the grouping of phrases (phrases) manifested by a musical artist or singer conveyed to the listener. Expressions must emerge from the heart. Talking expressions in music are about the expression (facial expression) how sad, happy, disappointed, and anxious the face is, but there are other elements in the expression. The aspects of expression in the art of music consist of 1) tempo (song speed and song speed changes), 2) dynamic (volume level or loudness and changes in loudness), 3) tone color is a characteristic of sounds that sound various -sorts, which are produced by different sound source materials and those produced by how to produce different tones $(\mathrm{Ku}-$ suma, 2011).

Furthermore, Jamalus (1988), expression in music is an expression of thoughts and feelings that include the tempo, dynamics, and tone colors of the main elements of music manifested by a musical artist or singer conveyed to the listener. In this way, 
the expression element is an element of feeling contained in a language sentence or a musical sentence. The songwriter or singer expresses the feelings contained in a song. The expression can also be interpreted as inspiration, where through the attitude of the whole person, an artist, singers, or musicians make a song "visible." Posture, hand gestures, and facial expressions of a person or several performers in a musical presentation visually complement what they convey with sound. Musical expressions are artistic, emotional expressions using tones, which are arranged according to certain rules, which are in the tradition of Western art music; these rules have a scientific character Tyasrinestu (2014). In other words, expression, including chanting prayers, will bring out various musical expression forms, considering that musical expression is an artistic, emotional expression using tone as a medium of expression.

Sholawat in the Arabic dictionary is the plural form of the word as found in the Munjid dictionary, صأدجاصنُالحاصُالح which means prayer (Ma'luf, 1986). The meaning of sholawat in terms of sholawat is perfect grace, the perfection of grace for his lover. It is called perfect grace because sholawat is not created, except for the Prophet Muhammad. Sholawat also means prayer, blessing, glory, prosperity, and worship (Abdillah, 1987).

For Muslims, the command to pray has actually been written in al-Qur'an, namely in the Al-Ahzab verse: 56, which means "Verily Allah and His angels pray for the Prophet. O you who believe, pray to the Prophet and say greetings of respect to him." Regarding the command to pray, in the context of Indonesian society, which consists of various cultures, the expression of sholawat will certainly be very diverse. In Indonesian society, there are various kinds of sholawat known, which vary in terms of presentation, composition, lyrics, and calendar when viewed in musical terms, Sholawat Badar, Sholawat Alfiyah, Sholawat Tibbil Qulub, and Sholawat Nariyah.

Several kinds of expressions of sholawat when viewed from the time of expres- sion that can be found around the community, for example: before adzan, in prayer readings, the time between the adzan and iqomah, before prayer, etc., or also in other moments such as in songs, videos, either solo or group performance. In these types of expressions, when viewed musically, it can be said that there are those that are presented acapella by several music groups, accompanied by musical accompaniment, or just present alone with or without musical accompaniment.

\section{METHOD}

This study is a descriptive qualitative study, with the primary approach being musicological. The target of the study is the musical expression of sholawat art in a multicultural society. Data were collected using observation, document study and documentation, and interviews. Data were analyzed using qualitative data analysis steps from Miles and Huberman.

The technique of checking the validity of the data was carried out in two ways: data triangulation and sources review. Furthermore, to analyze the sholawat art expression, it was carried out using several written sources related to composition theory, the science of harmony, and the form of music presentation.

\section{RESULTS AND DISCUSSION}

In the tradition of some Muslim communities, the activities of praying to the Prophet can be translated into various activities, for example, in reading barjanji, sholawat before congregational prayers, mauludan, and even during other religious events. The community's initial purpose in conducting sholawat event was solely to get the abundance of grace from Allah SWT. Apart from expecting blessings and mercy from Allah, the prayer program also reflects Muslims' love for the prophet $\mathrm{Mu}-$ hammad SAW.

Apart from being an expression of the love of the Islamic ummah to the Prophet Muhammad SAW which is con- 
tained in sharing forms of good activities in connection with a series of worship or memorials, the art of sholawat is also manifested in several ways, including 1) As part of Tasyahud in prayer, 2) Sholawat As a Prayer After Azan, 3) Prayers as part of a series of readings in the Jenazah Prayer (Mufidah \& Farida, 2020).

\section{Variety of Sholawat Expressions}

Based on the observations made, in the tradition of sholawat expression that develops especially in Indonesian Muslim communities, it can be found that the tradition of saying sholawat when viewed from the presence or absence of elemental content in a musical composition can be explained as follows.

Performed without songs: The expression of sholawat in this tradition is presented without the nuances of a musical composition (it does not contain elements of melody, bar, scale, form, harmony), presented gently. This expression of sholawat generally occurs in one part of the reading during the tasyahud in prayer, the part of the prayer reading during the funeral prayers.

Performed with a note (song): Praying sholawat with the nuances of this song can generally be found at several moments of time, for example, a) before the call to prayer (adzan) is pronounced, b) after adzan, c) humming sholawat (sung at the time between the adzan and iqomah, usually while waiting for the arrival of the imams and congregation), d) part of an agenda at the commemoration of the Islamic religious holidays, for example, the observance of the Prophet's birthday, reading the Barzanji book in the month of the Prophet Muhammad's birth, and e) music presentation, both in life and through recordings, both for business purposes and da'wah, as well as others.

Furthermore, based on the results of observations on a number of expressions of the art of sholawat both found in the recording media in the form of audio, video, or those found directly in the field, the various types of the sholawat can be categori- zed into several things as Figure 1-4.

\section{Based on a variety of scales}

Sholawat performance based on the category of scales used in the expression is divided into three types: sholawat using the major scale, sholawat using a minor scale, and sholawat using the pelog pentatonic scale. An illustration of the art of sholawat using major, minor, and pentatonic scales can be illustrated in the following notation.

\section{Based on lyric expression}

Based on field observations, various expressions of prayer have been found. Salawat is expressed in various forms from various sources such as audio recordings, videos, and those that occur directly in the field, for example, during the praising activities between the times of call to prayer and iqomah, the commemoration of religious holidays. The following are a form of expression.

The expression of sholawat taking the same verse but manifested in different melodic forms. For example, the song of Sholawat Badar strung together with the song Lir Ilir and popularized by Emha Ainun Nadjib (Najeeb, 2016), and an anonymous artist (in Album Sholawat Terbaru Channel, 2018) and the song popularized by the Wali Band group (Vidiolirik, 2009) are using different melody.

The Expression of sholawat manifested by taking melodies from songs which popular in society. The song is popular in society, for example: (1) Sholawat Badar, taking the melody from the song Ya Thoibah (Tekno Q, 2018), Sulis - Ya Thoybah (Malaysia, 2014), and Lir -ilir, popularized by the Kyai Kanjeng group led by Emha Ainun Najib (Najeeb, 2016); (2) The song Ya Rasulullah popularized by Ustad Jefri (Musikindo, 2013b) takes the melody of the Jablai song popularized by Titi Kamal (ASMR, 2019); and (3) Sholawat As-Sa'adah, (Nuralamsah, 2020) took part of the melody from the song Tombo Ati which was popularized by Opick (Musikindo, 2013a).

In summary, the expressions of sho- 


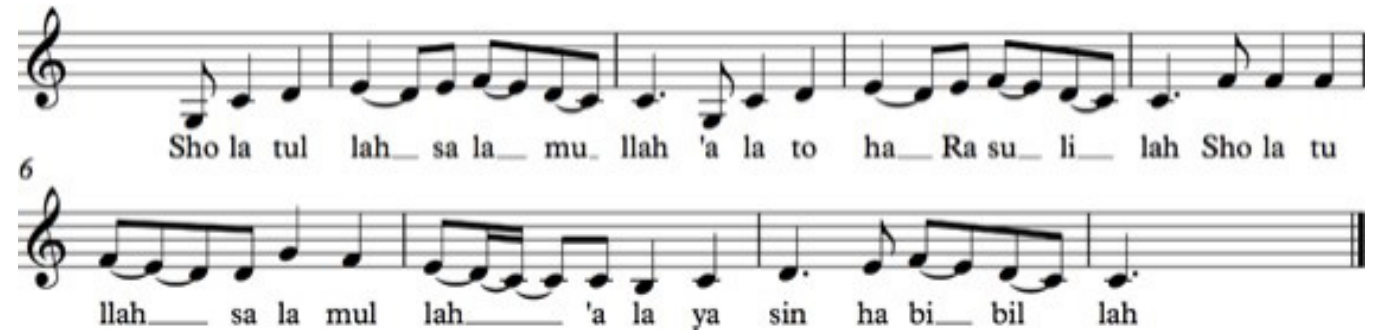

Figure 1. The Melody of Sholawat Badar in the major diatonic scale

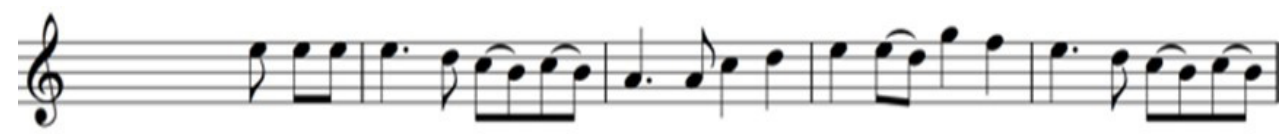

Sho la tul lah sa la_ mul lah 'a la to ha Ra_sul lil lah $\mathrm{Ra}_{\text {su_ lil }}$

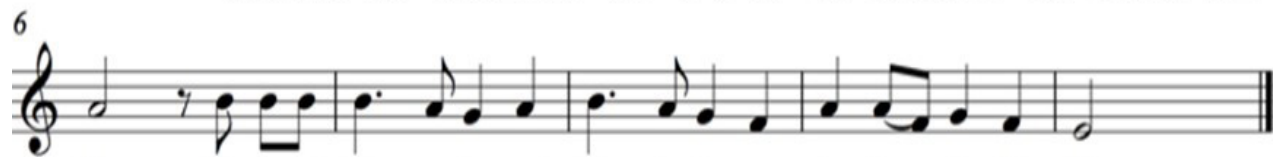

lah Sho la tul lah sa la mul lah 'a la ya sin ha_ bi bil lah

Figure 2. The Melody of Sholawat Badar in the Original Minor Diatonic Scale

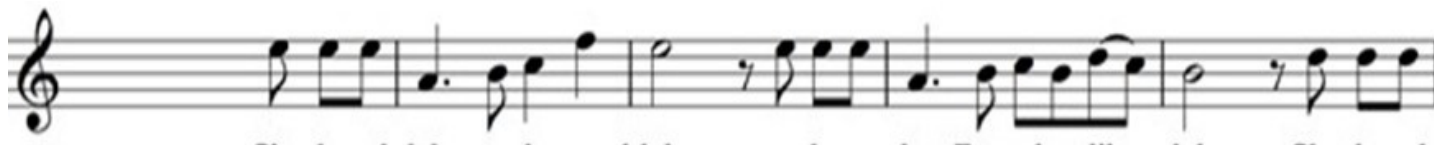

Sho la tul lah sa la_mul lah a la to ha Ra sul lil_ lah Sho la tul

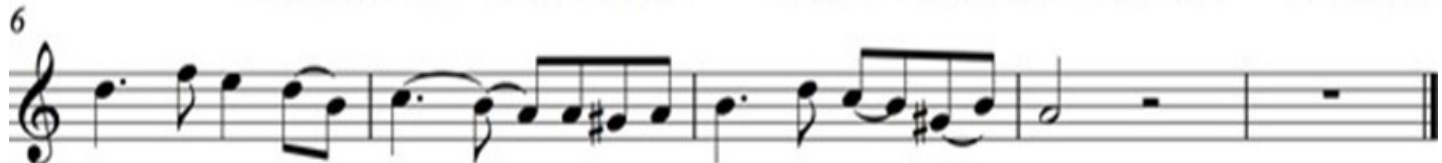

lah sa la mul. lah__a la ya sin ha bi_bil_ lah

Figure 3. The Melody of Sholawat Badar in Harmonious Minor Scales

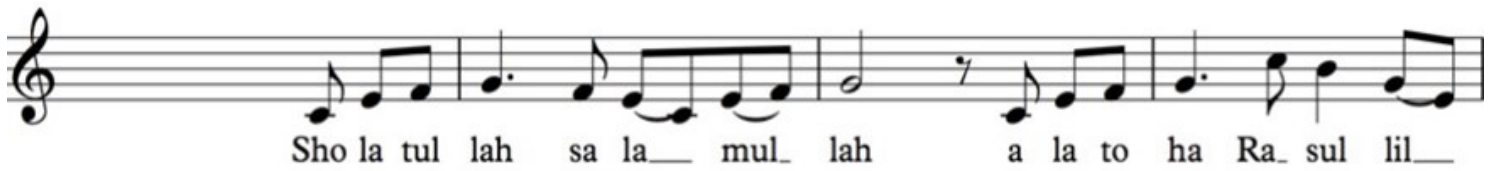

5

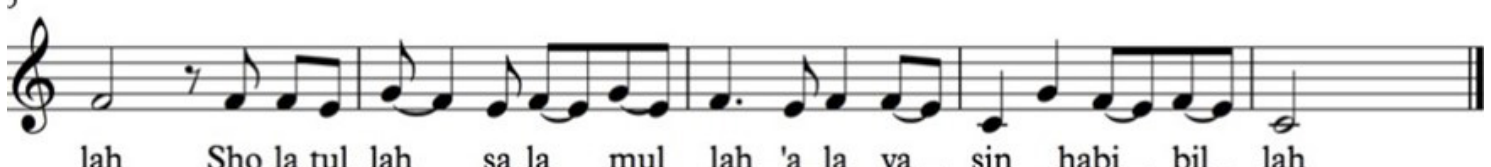

lah Sho la tul lah sa la mul lah_a la ya_ sin habi_bil_ lah

Figure 4. The melody of Sholawat Badar with Pentatonic scales (Javanese Pelog)

lawat manifested by taking melodies from songs that are popular in society can be arranged in the following Table 1.

Based on the similarity of melody and lyrics but different formats and genres

Based on the existing documents, various expressions of sholawat (Sholawat Badar) are also found with the same verse and melody but are presented in various different genres. Some illustrations of this form can be seen from the following examples.

Sholawat Badar with major scales in the Tradition Orchestra format (Gamelan): Indonesian Embassy in Abu Dhabi. The video on https://www.youtube.com/ watch?v=7LePxs6LfVM shows the form and genre (Wisnu, 2015).

Sholawat Badar dish with harmonious minor scales in the pop genre by Habib Syeh. The video link on https://www. 
Table 1. Title of Sholawat, The song title that its melody takes and the artist who performed it

\begin{tabular}{ll}
\hline Title of Sholawat & $\begin{array}{l}\text { The song title that its melody takes and } \\
\text { the artist who performed it }\end{array}$ \\
\hline Sholawat Badar & $\begin{array}{l}\text { Lir-ilir (Emha Ainun Najib), } \\
\text { Ya Thoibah (Nisa Sabyan, Sulis) }\end{array}$ \\
Ya Rasulullah Salamun 'Alaika & Jablay (Titi Kamal) \\
Sholawat As-Sa'adah & Tombo Ati (Opick) \\
\hline
\end{tabular}

Table 2. Variety of Sholawat Badr in Different Genres

\begin{tabular}{ccc}
\hline Type of Sholawat & Artist & Genre \\
\hline Sholawat Badar & Zuhra & Pop \\
Sholawat Badar & Lisna dkk & Dangdut \\
Sholawat Badar & FDJ Enily Family & Reggae \\
Sholawat Badar & Hadad Alwi & Keroncong \\
Sholawat Badar & Chrisyealah & Pop-Keroncong \\
Sholawat Badar & Nasida Ria & Nasyid \\
\hline
\end{tabular}

youtube.com/watch?v=wXeKP6fIWYI shows this format and genre (Berdakwah, 2019); and video Zuhra-feat 41 Project on the major scale on https://www.youtube. $\mathrm{com} /$ watch? $\mathrm{v}=$ FO4Soolp6BI do (Official, 2018)

Sholawat Badar presentation in the dangdut genre by Lisna et al on https://www.youtube.com/ watch? $\mathrm{v}=\mathrm{xRQ} 29 \mathrm{t} 8 \mathrm{cPbk}$ (Pajampangan, 2020); and on https://www.youtube. $\mathrm{com} /$ watch? $\mathrm{v}=\mathrm{D} 5 \mathrm{Bm} 1 \mathrm{PCa}$ Cg show the format and the genre.

Sholawat Badar in the genre of reggae: FDJ Emily Song on https://www. youtube.com/watch?v=WHScu2pGSkc shows the format and genre (ARD Management, 2019).

Sholawat Badar in the kroncong genre: Hadad Alwi on https://www. youtube.com/watch?v=Nk7-PoHD6XU (Baysem, 2015),: and Chrisye (Lu'Q, 2012) on https://www.youtube.com/ watch?v=hgrd3kjHg1Y (Lu'Q, 2012)

Sholawat Badar in the genre of $\mathrm{Na}-$ syid: Nasida Ria on https:/ / www.youtube. $\mathrm{com} /$ watch? $\mathrm{v}=\mathrm{YUx} 8 \mathrm{HD} 1 \mathrm{WTI}$ c shows this format and the genre of Nasyid (Najeeb, 2015).

The description above can be summarized as in Table 2.

\section{Based on the same melody but different lyrics}

The expression of sholawat in the form of presenting the same melody but using different lyrics is actually an expression of sholawat where a composition of the song is sung repeatedly. Still, in the first repetition, it is presented with different lyrics. Serving like this can be in the form of a vocal group or individual presentation. One of the expressions of prayer in this form is the Sholawat as-Sa'adah performance by the Neo Sholawat-Snada music group, which can be seen on the following youtube page (Indonesia, 2020). In simple terms, the expressions of prayer in this category can be written as Figure 5.

From the lyric expression which uses Arabic, then it is presented in the form of an expression with lyrics taken from various different languages, namely: a. Indonesian Language, b. English, c. Mandarin, d. Javanese language, e. Minangkabau language, with pauses in the presentation as follows

Ya Allah curahkanlah rakmat dan keselamatan / Bagi Nabi junjungan kami, Muhammad / Selamanya di dalam keabadian / Kekekalan Kerajaan-Mu, ya Allah // (in Indonesian Language)

Ya Allah, please shower your blessing and your salvation / To the Prophet Muhammad who we all adore / May he 
always is under your sovereignty / May he forever Is under your loving care // (in English)

Ya Allah kei wo men tien an heu keu lien / Ken lau se Muhammad yeh se aitha/Hau hen chiu chai tien an the / Allah teu keu lien wou men hau hen chiu / / (in Mandarin language)

Sunda Version: Ya Allah lungsur keun rahmat sinareng salamet / Kanggo Nabi junjungan kuring Muhammad / Salawasna aya dina kawilujengan / Salawasna ditang tayungan ku Allah // (in Sundanese)

Ya Allah paringono rakmat lan keslametan / kagem Nabi junjungan kulo Muhammad / Salamanipun wonten ing keselametan / Salamanipun diwelasi Gusti Allah / / (in Javanese)

Ya Allah curahkan jo kasalamatan / Taruntuak nabi piturui kami Muhammad / Sapanjang idui di dalam kabakaan / Salamonyo dalam kasiah saying Allah // (in Minangkabau language)

Based on the research results, it can be explained that there are various musical expressions that are found and developed in Indonesian society. This means that in the context of a multicultural society such as Indonesia, which is rich in various cultures, including a wide variety of artistic expressions, many musical expressions have developed in society.

The variety of expressions that have developed in this society can be in the form of pitched prayers (can be categorized as musical expressions) and not pitched. There are also scales that use major and minor diatonic scales and pentatonic scales (pe$\log )$, as well as the use of various lyrics and different languages but with the same melody or in one type of musical composition, or different melodies and lyrics.

The expression of sholawat that does not use songs is possible if the expression of the prayer is still related to a religious ritual so that the expression in this context is not sung. This means that the chanting of sholawat means that the expression of prayer at that time is an integral part of worship that is being carried out, so that there is a concern that chanting sholawat with songs will affect his specialty in prayer/worship. This is in line with Qurrata A'yuni's opinion that praying sholawat to the Prophet contains two main prayers, namely prayers and blessings to the Prophet (A'yuni, 2016). As a prayer, of course, in expressing it also according to the existing guidance, namely in a soft and hopeful voice, as recommended in the $\mathrm{Al}$ Quran surah al A'rof verse 55, which means praying to your Lord with a humble self and a soft voice. Allah does not like people who transcend boundaries (Surah al A'raf: 55). Furthermore, it is also emphasized that the ethics in performing prayer directly related to a prayer or worship activity is that praying to Allah SWT cannot be done carelessly. One of the good manners in praying to be granted by Allah SWT is to read sholawat (Zaki, 2020).

The use of different lyrics in the sholawat art using melodies in various scales, both diatonic major, minor, and pelog pentatonic scale is possible. This possibility is because of the touch and association

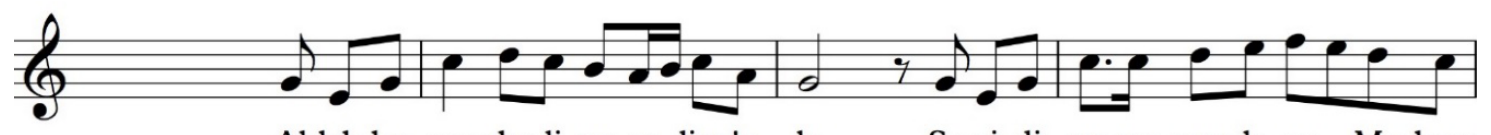

Al lah hu ma sho li wa sa_lim 'a la Sa yi di na wa mau la na_ Mu ham

5

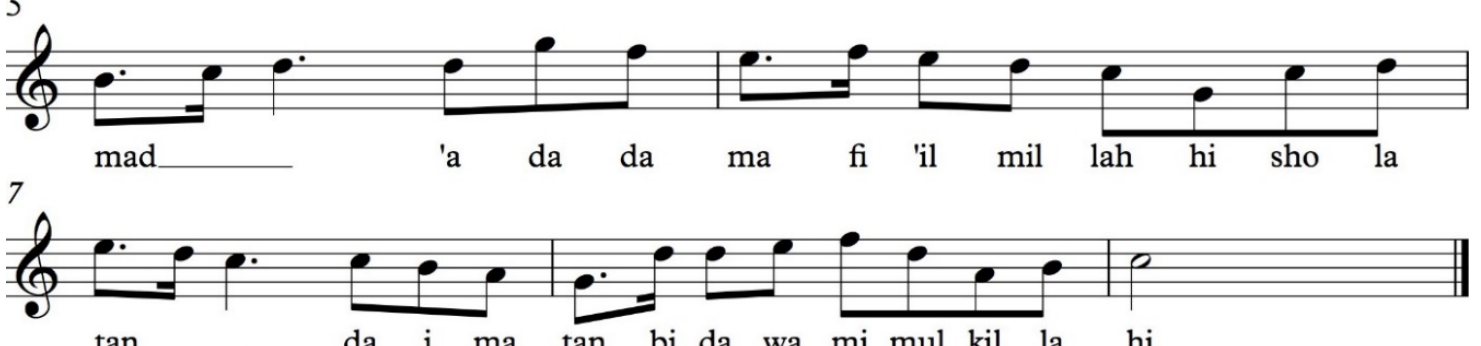

$\tan$

Figure 5. Sholawat Sa'adah (popularized by Neo Sholawat) 
with the developing arts and often consumed by community members who use the prayer (sholawat) to associate with a music tradition; the music tradition they often associate with will form a musical tradition a person.

In short, if someone often associates with music traditions with diatonic levels, either major or minor, then this tradition will appear when he expresses his music. In other words, the appearance of a person's musical expression is influenced by his association with a musical tradition that he often encounters. This is in line with the opinion that each person/group has their way of expressing music to differentiate between one group and another (Shaleha, 2019). Likewise, the diversity of music cultures that exist and develop in Indonesia is also very likely to even color and influence someone in expressing their music. In other words, the emergence of the diversity of musical expressions in the sholawatan art is thought to be due to the influence of the conditions of musical cultural diversity that develop in the multicultural society.

Music should also be understood in terms of meaning and value by playing music and listening in a cultural context (Elliot, 1995). Music is multicultural because, in the societies such as Indonesia, all music types exist from various original cultural backgrounds, such as Chinese, Indian, and Jazz, to Baroque music (Elliot, 1995). Because music is everywhere and consists of various musical, cultural differences, music's nature is multicultural or diverse. The art that is generally played by the Muslim community cannot be separated from the influence of the multicultural society. Musical compositions and musical expression that emerged was a lot of that comes from cross-genre and cross-culture where the music was coming.

\section{CONCLUSION}

Based on the results and discussion, it can be concluded that the musical expression of the sholawat art in a multicul- tural society gives rise to various musical expressions of sholawat art. Some of the musical expressions of sholawat art appear the diversity of presentation in relation to the timing of the melody/scale, and language and musical genres. The variety of expressions of this sholawat art is possible.

\section{REFERENCES}

Album Sholawat Terbaru Channel. (2018). Bikin Nangis. Sholawat Badar Paling Merdu Terbaru 1 Sholawat Nabi-YouTube. https://www.youtube.com/ watch? $\mathrm{v}=\mathrm{S} 6 \mathrm{LNjsub0R0}$

Aini, A. F. (2020). Living Hadis dalam Tradisi Malam Kamis Majelis Shalawat Diba'Bil-Mustofa. Ar-Raniry, International Journal of Islamic Studies, 2(1), 221-235.

ARD Management. (2019). FDJ Emily Young-Sholawat Badar (Official MusicVideo) | Reggae-YouTube.Youtube.https:/ / www.youtube.com/ watch? $\mathrm{v}=$ WHScu $2 \mathrm{pGSkc}$

ASMR, A. (2019). Lirik Jablai-Titi kamalYouTube.https://www.youtube. com/watch? $\mathrm{v}=$ adUWHXWS8jw

A'yuni, Q. (2016). Sholawat Kepada Nabi Dalam Perspektif Hadis. Substantia, 18(2), 165-182.

Ambarwangi, S. (2013). Pendidikan Multikultural di Sekolah Melalui Pendidikan Seni Tradisi. Harmonia: Journal of Arts Research and Education, 13(1).

ARD Management. (2019). FDJ Emily Young-Sholawat Badar (Official Music Video)|Reggae-YouTube. https: / / www.youtube.com / watch?v $=$ WHScu 2 pGSkc

ASMR, A. (2019). Lirik Jablai-Titi kamalYouTube. https://www.youtube. $\mathrm{com} /$ watch? $\mathrm{v}=$ adUWHXWS8jw

Baysem. (2015). Haddad Alwi Sholawat Badar Ilahisi Orjinal Klip HD-YouTube. https://www.youtube.com/ watch? $v=$ Nk7-PoHD6XU

Berdakwah, E. C. (2019). Habib Syech-Sholawat Badar. YouTube https: / / www.youtube.com / watch? $v=w X e K P 6 f I W Y I$ 
Banks, J. A. (1999). An Introduction to Multicultural Education (2nd ed.). Boston: Allyn and Bacon.

Banks, J. \& C. Bank. (1993). Multicultural Education: Issues and Perspective (Second Edition). Boston, MA: Allys and Bacon.

Baysem. (2015). Haddad Alwi Sholawat Badar Ilahisi Orjinal Klip HD - YouTube. Youtube. https://www.youtube. com/watch?v=Nk7-PoHD6XU

Berdakwah, E. C. (2019). Habib Syech - Sholawat Badar. - YouTube. Youtube. https://www.youtube.com/ watch? $v=w X e K P 6 f I W Y I$

Dloyana, K., I Made P., dan Sukiyah. (1995). Pesan-pesan Budaya Lagulagu Pop Dangdut dan Pengaruhnya terhadap Perilaku Sosial Remaja Kota. Jakarta: Direktorat Sejarah dan Nilai Tradisional Direktorat Jenderal Kebudayaan.

Elliot, D. J. (1995). Music Matters : A New Philosophy of Music Education. Oxford University Press.

Fahruroji, \& Azhar, Y. C. (2017). Perspektif Sholawat dalam Al-Quran dan Al-Hadits Serta Implikasinya dalam Penafsiran dan Penetapan Hukum. Jurnal Pendidikan Basis, I(1), 31-40.

Indonesia, K. J. (2020). Neo Sholawat - Snada - YouTube. Youtube. https:/ / www.youtube.com/ watch?v=tuvYNZHpFVQ

Jamalus. (1988). Pengajaran Musik Melalui Pengalaman Musik. Jakarta: Depdikbud.

Kusuma, R. C. (2011). Harmoni, Struktur Lagu dan Ekspresi dalam Musik - Kompasiana.com. Kompasiana. https:// www.kompasiana.com/robby_ uns/55006382813311fb16fa7787/ harmoni-struktur-lagu-dan-ekspresi-dalam-musik

Lu'Q,Y.(2012).Chrisye-SholawatBadar-YouTube. Youtube. https://www.youtube.com/watch? $\mathrm{v}=$ hgrd3kjHg1Y

Ma'luf, L. (1986). Al-Munjid. Dar elMasSyriq.

Malaysia, N. S. R. (2014). Sulis - Ya Thoybah (Official Music Video) - YouTube. You- tube. https://www.youtube.com/ watch? $\mathrm{v}=\mathrm{q}$ Ybei6hP6R8

Mufidah, R. L., \& Farida, N. A. (2020). Tradisi Sholawat Mansub Habib Sholeh Bin Muhsin Al-Hamid di Tempeh Tengah, Lumajang. Jurnal Living Hadis, 5(1), 59.

Muhammad Bin A. Bakrin Ayub Az-Zur'i Abu Abdillah. (1987). Jalaul Afham Fi Fadhlis Sholati Ala Muhammad Khoirul Anam (Jalaul Afham Ibnu Qoyyim) Syamilah). (Second Edi). Urubah.

Musik, C. (2020). Sholawat Badar Versi Alunan Jawa Mantepp - YouTube. Youtube. https://www.youtube.com/ watch? $v=$ pv6LNHdZL7A

Musikindo, A. (2013a). Opick - Tombo Ati | Official Video - YouTube. Youtube. https://www.youtube.com/ watch?v=ul6ZiwZ7heQ

Musikindo, A. (2013b). Ustad Jefri Al Buchori - Ya Rasulullah | Official Lyric Video - YouTube. Youtube. https://www.youtube.com/ watch?v=Qc_2G2hRRgg

Najeeb, M. A. (2015). nasida ria - sholawat badar - YouTube. Youtube. https://www.youtube.com / watch?v=YUx8HD1WTIc

Najeeb, M. A. (2016). Cak Nun dan Kiai Kanjeng---lir ilir+Sholawat Badar - YouTube. Youtube. https://www.youtube.com/watch?v=KN5KuQ8B-gU

Nuralamsah, R. (2020). Sholawat As-sa'adah (tombo ati), allahuma shali wa salim ala (full version) lirik - YouTube. Youtube. https://www.youtube.com/ watch? $\mathrm{v}=4 \mathrm{a} 5$ Nyrlat08

Official, 41 Project. (2018). Sholawat Badar Zuhra Feat 41 Project - YouTube. Youtube. https://www.youtube.com/ watch? $\mathrm{v}=\mathrm{FO} 4$ Soolp6BI

Pajampangan, G. (2020). Sholawat Badar Cover By Lisna Dkk - YouTube. Youtube. https://www.youtube.com/ watch? $\mathrm{v}=\mathrm{xRQ} 29 \mathrm{t} 8 \mathrm{cPbk}$

Parekh, B. (2001). Rethinking Multiculturalism: Cultural Diversity and Political Theory. Ethnicities, 1(1), 109-115.

Poole, R. (1997). National identity, multiculturalism, and aboriginal rights: 
An Australian perspective. Canadian Journal of Philosophy, 26(1), 407-438.

Suharto. (1996). Pendidikan Multikultural Melalui Pendidikan Seni Musik. Seminar Nasional Pendidikan Seni, 163-170.

Tekno Q. (2018). Ya Thoyoibah Nisa Sabyan Ganbus (lirik) - YouTube. Youtube. https://www.youtube.com/ watch?v=d9HAGzyEfY4

Tutik, T., Ulfa, U., \& Fikri, M. T. (2020). Pujian Setelah Adzan Untuk Perkembangan Kecerdasan Spiritual Anak. At-Tuhfah: Jurnal Studi Keislaman, 9(1), 56-65.

Vidiolirik. (2009). Wali - Mari Sholawat (Lirik) - YouTube. Youtube. https: / / www.youtube.com / watch?v=ivLEGhPbe8g

Wahyuni, U., \& Pujiyanti, R. (2019). Makna Konotatif Syair Qasidah Salawat Nabi Pada Naskah Majelis Dzikir Dan Salawat Pondok Rumi Untuk Majelis Al-Asyiqin Jambi (Kajian Se- mantik). Aksara: Jurnal Ilmiah Pendidikan Bahasa dan Sastra Indonesia, 3(1), 112-121.

Wisnu, S. (2015). Salawat Badar - Javanese Gamelan Music - KBRI Abu Dhabi [HD] - YouTube. Youtube. https: / / www.youtube.com / watch?v=7LePxs6LfVM

Zaki, A. G. (2020). Keutamaan Sholawat kepada Nabi SAW, Berikut Hadis-Hadis yang Mendukungnya - Portal Jember. Portal Jember. https:// portaljember. pikiran-rakyat.com/khazanah/pr16641375/keutamaan-sholawat-kepada-nabi-saw-berikut-hadis-hadisyang-mendukungnya

Wahyuni, U. \& Rini P. (2019). Makna Konotatif Syair Qasidah Salawat Nabi Pada Naskah Majelis Dzikir Dan Salawat Pondok Rumi Untuk Majelis Al-Asyiqin Jambi (Kajian Semantik). Aksara: Jurnal Ilmiah Pendidikan Bahasa dan Sastra Indonesia, 3(1), 112-121 